DOI: 10.24193/OJMNE.2021.36.02

\title{
GENETIC TESTING IN INSURANCE: IMPLICATIONS FOR NON-EU INSURANCE MARKETS AS A PART OF THE EUROPEAN INTEGRATION PROCESS
}

Mykhailo ARYCH, PhD.

National University of Food Technologies, Department of Finance, Ukraine mykhailo.arych@gmail.com Mariia LEVON, PhD. Bogomolets National Medical University, Department of Operative Surgery and Topographic Anatomy, Ukraine mariia_levon@ukr.net Halyna ARYCH, PhD.

Hospital Medical Officer, Mildura Base Public Hospital, Mildura, Australia harych@mbph.org.au Yurii KULYNYCH, PhD.

National University of Food Technologies, Department of Finance, Ukraine iurii.kulynych@gmail.com

\begin{abstract}
The purpose of the research study is to investigate the implications peculiarities of genetic testing in insurance for non-EU insurance markets as a part of the European integration process. The research model was developed by reviewing the previous studies in the area of genetic testing in insurance. Also, it was applying the correlation-regression analysis for defining the relationship between the causes of death and life insurance market competitiveness in the context of genetic testing in insurance implications for non-EU insurance markets as a part of the European integration process. The originality of the study is explained by the fact that it was described the genetic testing in insurance implications for non-EU insurance markets as a part of the European integration process; secondly, for the first time was conducted the correlation-regression analysis of the interconnection of causes of death and life insurance market competitiveness (case study of Ukrainian insurance market) in the context of genetic testing in insurance implications for non-EU insurance markets as a part of the European integration process). The scientific value of the research results also is explained vie the possibility of apply these findings for start to regulate the using of the genetic testing for risk assessment at the Ukrainian life insurance market and in others European countries that are not members of the EU and in EU countries that do not have any specific regulations in the area of applying genetic testing technologies for risk assessment in insurance.
\end{abstract}

Keywords: insurance, genetic testing, genetic discrimination, European Union, integration, human rights protection.

\section{Introduction}

Applying genetic testing technologies for risk assessment in insurance is not a new underwriting method at the international level. For example, a very big experience of it have 
United States, Canada, Australia, Germany, Netherlands, Norway etc. However, not every country of European Union (EU) and even Europe as whole has at least a small experience in regulation of using genetic testing for insurance purposes. That's is why it is importantly to study the genetic testing in insurance implications for non-EU insurance markets as a part of the European integration process.

Additionally, we strong believe that applying genetic testing for underwriting in insurance can be a significant step for improving both the health care system (early detection diseases, increase the treatment of diseases, etc.) and risk assessment in life and health insurance. These advantages can make a lot of competitiveness benefits for life insurance market and health care system as whole. For example, the most earlies research results of its topic were explored by Pokorski (1991), McEwen et al. (1992), McEwen et al. (1993), Pokorski (1997), and Knoppers \& Joly, (2004). The later discussions about genetic testing in insurance were related to the genetic discrimination (Prince, 2016); cancer treatment and diagnosing (Lane et al., 2015; Dalpe et al., 2017); personal and health insurance (Riba, 2017; Barlow-Stewart et al., 2018; Newson et al., 2018); clinical genetics and genome sequencing in health adults (Tiller et al., 2018; Zoltick et al., 2019). Thus, the interconnection between health care system and insurance market can make much more benefits for society if this relationship will be based on the scientific approaches and high technologies. Besides, taken in consideration the influence of health status and mortality factors on life insurance (Santos et al., 2017; Tsendsuren et al., 2018; Serykh \& Yang, 2019; etc.) it is necessary to investigate the interconnection between the causes of death and life insurance market competitiveness as a part of genetic testing in insurance implications model. Because, genetic testing results can be very effective for risk assessment in life and health insurance, and also for diseases' detection, treatment and diagnosing of diseases. Consequently, its ones again explain the reason why we have decided to study the relationship between the causes of death and life insurance efficiency and competitiveness.

Hence, in this article, we continue a series of our scientific studies (the first-one was about use of genetic testing in life and health insurance (Arych and Levon, 2019) to investigate the necessity and relevance of implementing a risk assessment system in insurance through the genetic testing technologies for Ukrainian insurance market in the context of its European integration process. Furthermore, the results obtained in this study will be useful also for a lot of others nonEU countries (as a part of the European integration process) and their insurance markets as part of 
a system for implementing the use of genetic testing as a new a high-tech tool and method for risk assessment in life and health insurance.

The aim of the study includes the following items: first, to investigate the implications peculiarities of genetic testing in insurance for non-EU insurance markets as a part of the European integration process (studying the international approaches for human rights protection through the using genetic testing technologies for insurance purposes; defining the benefits of genetic testing for insurance and health care system; assessing the factors influencing the insurance market: general, health status and mortality factors; analyzing the interconnections between causes of death and life insurance market competitiveness in the context of genetic testing in insurance implications for non-EU insurance markets as a part of the European integration process).

The novelty of the research can be argued according by the fact that, firstly, it was described the genetic testing in insurance implications for non-EU insurance markets as a part of the European integration process; secondly, for the first time was conducted the correlation-regression analysis of the interconnection of causes of death and life insurance market competitiveness (case study of Ukrainian insurance market) in the context of genetic testing in insurance implications for non-EU insurance markets as a part of the European integration process). Furthermore, the scientific value of the research results also is explained vie the possibility of apply these findings for start to regulate the using of the genetic testing for risk assessment at the Ukrainian life insurance market and in others European countries that are not members of the EU and in EU countries that do not have any specific regulations in the area of applying genetic testing technologies for risk assessment in insurance. It also will contribute to improve the efficiency and competitiveness of the insurance market and the health care system. Because the more widely using genetic testing technologies in insurance will have a positive impact on the disease detection process at their early stages that are related to the more effective treatment.

The research study is organized as follows. The first section describes the aim of the research topic, its novelty, and introduces its structure. Section 2 outlines the theoretical background and literature review of the genetic testing in insurance implications for insurance markets. Section 3 describes the international approaches for human rights protection as a part of using genetic testing technologies in underwriting; analyzes the benefits and advantages of genetic testing for insurance and health care system; describes the factors influencing the insurance market: general, health status and mortality factors; estimates the interconnection between the causes of death and life 
insurance market competitiveness in the context of applying the genetic testing in insurance model for non-EU insurance markets as a part of the European integration process. Finally, the last section summarizes the research results, empirical findings and suggests directions for future research directions. Hence, the research study provides a comprehensive analysis of the genetic testing in insurance implications for non-EU insurance markets as a part of the European integration process. The results of its discussions will useful for establishing the regulation of applying genetic testing technologies in the underwriting process for European and other countries that do not legally use genetic results in insurance.

\section{Theoretical Background}

Today genetic testing technologies are very popular and widespread as a underwriting method in insurance in many countries, including in Europe. However, the history of genetic implication for insurance market is still not very long. Nowadays we exactly know that in the early 1970s some insurers in the U.S. denied of insurance protection or increased insurance rates (premiums) for African Americans who had a gene for sickle cell anemia (Andrews, 1987). But, the expansion and rapid development of applying genetic testing in insurance became possible after the international Human Genome Project (NHGRI, 2003) research results. According to its scientific goal it was reflected the entire human genome in 2003 (Genetic screening ethical issues, 1993). In addition, there are about 70,000 genetic testing products in the market (Health Plan Landscape for Genetic Testing, 2018) that give a lot of high-quality risk assessment opportunities in insurance market (Lemmens T., Joly Y., Knoppers B., 2004). But, applying genetic testing technologies for insurance market also have a many issues and challenges, for example, genetic discrimination (Boyer-Kassem T., Duchene S., and Engelen B., 2017; Nicholls S.G., Joly Y., Moher E., Little J., 2014) and adverse selection (information asymmetry) (Thomas R. Guy, 2018). That's why, the world and European experience show that there are different approaches for genetic testing regulation in insurance, for example, 'human rights', 'therapeutic limit', 'legislative

prohibition', 'quality control system', 'moratorium', 'proportional approach', and 'status quo' (Lemmens et al., 2004). Today, different European countries have different approaches for applying genetic testing technologies in insurance. For, example, United Kingdom, Germany, and the Netherlands have defined that insurance companies have the right to require from insurance applicants the results of genetic testing if there are plans to sign insurance policy with very big 
insurance coverage (Office of the Privacy Commissioner of Canada, 2012; Durnin M., Hoy M., Ruse M., 2012). Altogether, another group of countries, for instance, Austria, Belgium, Denmark, Finland, and Norway, have decided to use the principles of avoiding the genetic discrimination in insurance. Here, in these European countries there are legislative prohibitions for using and requesting genetic testing results of insurance applicants for risk assessment in insurance (Canadian Coalition for Genetic Fairness; Goel S., 2018).

Furthermore, Nabholz C.E. (2011) studying the fair risk assessment in life and health insurance argued that such type of regulation approaches for genetic testing in insurance as 'ban of using' is related to France and Portugal. Its method means that government may prohibit insurance companies from applying genetic testing results for underwriting process. 'Limitation by law' - related to Switzerland (there are different regulation approaches health and life insurance); 'moratorium' - in Sweden where using a voluntary moratorium not to apply genetic testing results in insurance. Also, in the European level, Klein (2017) defined that in Greece there is not any specific genetic testing in insurance regulations, however insurance companies voluntarily may do not request any genetic data before making insurance agreement with policyholders. Additionally, in Ireland - genetic testing results can be collected, but, like in Poland, it does not allow to apply this information for underwriting process; in Spain - it is prohibited any form of genetic discrimination, but altogether there is not any regulations that specifically applying for insurance market.

In general, just over ten European Union (EU) countries and some non-EU members (which have already been described previously in the research paper) have its own regulations in the area of applying genetic testing technologies and results in insurance for risk assessment. Another group of EU-countries, for example, Bulgaria, Croatia, Republic of Cyprus, Czech Republic, Hungary, Romania, Slovakia, Slovenia etc., do not have any specific legislative regulations that are related for interconnection between insurance and genetic testing. Altogether, this paper research analysis shows that some high-development non-EU members use highly specialized approaches for genetic testing in insurance regulations (for instance, United Kingdom, Switzerland, Norway). However, a lot of the European countries that are not members of the EU do not have any specific regulations in this area. This list of non-EU members can include Ukraine, Serbia, North Macedonia, Montenegro, Bosnia-Herzegovina, Albania, Moldova, Iceland, Monaco, Andorra, San Marino, Liechtenstein, Russia, Belarus, Georgia, etc. 
Thus, we strong believe, that these countries could be more successful applying genetic testing results in insurance for development health care system, because genetic technologies give us a lot of advantages for disease prediction and risk assessment, and the new era of medicine - it is a genetic medicine. In addition, here the main questions how to protect people from genetic discrimination, and how to avoid adverse selection (information) during applying genetic testing technologies for insurance purposes.

\section{Methods and methodology}

The research methodology of this paper is conducted through two parts: firstly, it is a systematic and critical literature review of human genetics and insurance studies, and, secondly, our methodology based on the competitiveness indicators and correlation-regression analysis. About 200 articles and research papers were analysed. Searches were conducted from May 2018 on PubMed, Google Scholar, ResearchGate, ScienceDirect and other internet-based resources with various permutations of the following keywords: 'human genetics', 'insurance', 'genetic discrimination', 'life insurance', 'information asymmetry' and 'genetic test'. As a result, a list of more than sixty publications most directly associated with human genetics and insurance was obtained. The selected publications were used as a theoretical background for this paper.

The interconnection between the causes of death and life insurance market competitiveness was analyzed based on the research methodology as follows:

i) insurance penetration, that shows the share of insurance in the formation of GDP on the basis of insurance premiums of insurers and is calculated as follows (Shirinyan, 2014; Das \& Shome, 2016; Rakshit, 2017; Chizoba et al., 2018):

$$
\eta_{\text {Total }}=100 \% \times T G P_{\text {Total }} / G D P,
$$

where, $\eta_{\text {Total }}$ - insurance penetration based on total gross premiums; $T G P_{\text {Total }}$ - total gross premiums; GDP - gross domestic product;

ii) life insurance share - calculated as the ratio of life insurance market premiums to the total insurance premiums in the country (Shirinyan, 2014):

$$
\eta_{\text {Life }}=100 \% \times T G P_{\text {Life }} / T G P_{\text {Total }},
$$

where, $\eta_{L i f e}-$ life insurance penetration based on total life insurance premiums; TGP $P_{L i f e}-$ total life insurance premiums; 
iii) gross claim payments rate or claims payments rate - calculated as the ratio of insurance payments to insurance premiums (Bikker, J., \& Popescu, A., 2014; Fagart, M.C. et al., 2002; Grmanová, E., \& Strunz, H., 2017):

$$
\gamma_{\text {Total }}=100 \% \times G C P_{\text {Total }} / \text { TGP }_{\text {Total }}
$$

$\gamma_{\text {Total }}$ - gross claim payments rate or claims payments rate, $\%$; $G C P_{\text {Total }}$ - gross claim payments of the total insurance market;

$$
\gamma_{\text {Life }}=100 \% \times G C P_{\text {Life }} / T G P_{\text {Life }}
$$

$\gamma_{\text {Life }}$ - life insurance claim payments rate, $\% ; G C P_{L i f e}-$ life insurance gross claim payments;

iv) percentage share of each individual cause of death calculated as the ratio of the number of persons who died from a specific cause of death $(\mathrm{X} 2, \mathrm{X} 3 \ldots \mathrm{X} 20)$ to the total number of deaths during the year $(\mathrm{X} 1)$ :

$$
\mathrm{SD}_{\mathrm{n}}=100 \% \times \mathrm{X}_{\mathrm{n}} / \mathrm{X} 1
$$

$\mathrm{SD}_{\mathrm{n}}$ - specific gravity (share) of $n$-cause of death in the total of all deaths (share of deaths); $\mathrm{X}_{\mathrm{n}}$ - number of deaths during the year from each $n$-cause of death ( $n$ - takes values from 2 to 20); $\mathrm{X} 1$ - the total number of people who died within a year of all $n$-causes together.

The list of death causes used in this research meets the international standards for the classification of death causes and diseases presented in Table 1.

Tab. 1 - The list of indicators of death causes and their designation for correlationregression analysis

\begin{tabular}{|l|c|}
\hline \multicolumn{1}{|c|}{ Causes of death } & $\begin{array}{c}\text { Indicators } \\
\text { X1-X20 }\end{array}$ \\
\hline Total deaths & $\mathrm{X} 1$ \\
\hline Certain infectious and parasitic diseases & $\mathrm{X} 2$ \\
\hline Neoplasms & $\mathrm{X} 3$ \\
\hline $\begin{array}{l}\text { Diseases of the blood and blood-forming organs and certain disorders involving } \\
\text { the immune mechanism }\end{array}$ & $\mathrm{X} 4$ \\
\hline Endocrine, nutritional and metabolic diseases & $\mathrm{X} 5$ \\
\hline Mental and behavioral disorders & $\mathrm{X} 6$ \\
\hline Diseases of the nervous system & $\mathrm{X} 7$ \\
\hline Diseases of the eye and adnexa & $\mathrm{X} 8$ \\
\hline Diseases of the ear and mastoid process & $\mathrm{X} 9$ \\
\hline Diseases of the circulatory system & $\mathrm{X} 10$ \\
\hline Diseases of the respiratory system & $\mathrm{X} 11$ \\
\hline Diseases of the digestive system & $\mathrm{X} 12$ \\
\hline Diseases of the skin and subcutaneous tissue & $\mathrm{X} 13$ \\
\hline Diseases of the musculoskeletal system and connective tissue & $\mathrm{X} 14$ \\
\hline Diseases of the genitourinary system & $\mathrm{X} 15$ \\
\hline
\end{tabular}




\begin{tabular}{|l|c|}
\hline Pregnancy, childbirth and the puerperium & X16 \\
\hline Certain conditions originating in the perinatal period & X17 \\
\hline Congenital malformations, deformations and chromosomal abnormalities & X18 \\
\hline $\begin{array}{l}\text { Symptoms, signs and abnormal clinical and laboratory findings, not elsewhere } \\
\text { classified }\end{array}$ & X19 \\
\hline External causes of mortality & X20 \\
\hline
\end{tabular}

Source: based on the State Statistics Service of Ukraine.

v) correlation-regression analysis to assess the interconnection between life insurance competitiveness and causes of death. In this research, we used a one-factor regression model where the equation of pair linear regression is constructed as $\mathrm{Y}=\mathrm{A}+\mathrm{BX}$. The number of persons who died from various causes of death was selected as factor variables X1, X2-X20; the objective functions of the analysis (main competitiveness indicators for the research) are the economic performance of the insurance market, namely gross premiums of the life insurance market in million UAH (Y1 $\left.=T G P_{\text {Life }}\right)$ and gross insurance claims payments of the life insurance market in million UAH (Y2 $\left.=G C P_{\text {Life }}\right)$.

\section{RESULTS AND DISCUSSION}

\subsection{Genetic testing in insurance: approaches for human rights protection}

Using genetic testing technologies in insurance has a lot of benefits, for example, highquality risk assessment, improving health care system, etc. But, altogether, one of the main problems here - how to avoid genetic discrimination (human rights protection) and what is the compromise answer will be positive for insurance companies and policyholders? In this context, at the international level according to the Article 6 of the Universal Declaration on the Human Genome and Human Rights (29th session of the UNESCO General Conference, 1997) it was protected people from any form of genetic discrimination. Later, in 2003 it was adopted the International Declaration on Human Genetic Data (IDHGD) by UNESCO according to which human genetic data and biological samples should not be disclosed to third parties (for example, employers, insurance companies, educational institutions and the family) (Canadian Coalition for Genetic Fairness). Furthermore, in Europe persons are protected from any form of genetic discrimination according to the Convention on Biomedicine, 1997 (Rothstein M.A., Joly Y., 2009). 


\subsection{Benefits of genetic testing for insurance and health care system}

For the purposes of our research paper, it is important to analyze benefit of genetic testing in insurance, and as a result - to describe the opportunities of its for improving health care system. Applying genetic testing technologies (for example, whole genome sequencing) for the assessment of the risk of common diseases makes underwriting process more effective (Nicholls et al., 2014). Besides, it is creating much more bigger opportunities for defining and predicting genetic diseases. According to Lombardo (2018), different genetic testing technologies and genetic tests show very important information for insurance and risk assessment. For example, breast cancer (75\%), hypertrophic cardiomyopathy (69\%), dilated cardiomyopathy (75\%), arrhythmogenic right ventricular cardiomyopathy (75\%), long QT syndrome (25\%), Brugada syndrome (75\%), Huntington's disease (95\%), polycystic kidney disease (100\%), myotonic dystrophy (75\%), Alzheimer's disease, early onset-autosomal dominance (100\%), hereditary nonpolyposis colorectal cancer (50\%), Marfan's syndrome (50\%), and catecholaminergic polymorphic ventricular tachycardia (75\%). This finding suggests that applying genetic technologies for underwriting purposes can be very positive and can have a lot of benefits for disease risk predictions and its also can have a very big impact for improving health care system.

Thus, studying the genetic testing in insurance implications for non-EU insurance markets as a part of the European integration process it is important to analyze population mortality trends by cause of death and its relationship to the individual life insurance market. In addition, we are going to study this area as factors influencing the insurance market through the general, health status and mortality factors that influence for non-life and life insurance markets.

\subsection{Factors influencing the insurance market: general, health status and mortality}

\section{factors}

World experience of studying the efficiency and competitiveness of the life and non-life insurance market shows that there are a lot of factors affecting on it. For instance:

i) economic factors: management expenditure, interest rate, size, leverage, Real GDP (Shawar \& Siddiqui, 2019), inflation (Daare, 2016), unemployment rate, wages and interest rate (Burić et al., 2017);

ii) demographic factors: age structure (Ćurak et al., 2013; Burić et al., 2017; Gemmo \& Götz 2016); 
iii) health status and mortality factors (Santos et al., 2017; Tsendsuren et al., 2018; Serykh \& Yang, 2019; etc.).

Thus, Priyan \& Selvakumar (2012) have argued that the main factors influencing the life insurance product determination are protection, customer service, maturity period, diversity of products, loan facility, revival and risk coverage. Also, the findings of the Yildirim \& Çakar (2015) reveal factors that affecting the insurance company preferences of insurance agencies such as financial aspects, satisfaction and communication. Significance research results of studying the factors influencing the life insurance market are presented by Sulaiman et al. (2015). The author suggests that inflation has a statistically noticeable negative impact on the demand and supply. In addition, there was a statistically significant negative effect of young dependency ratio on demand; and, old dependency ratio had a statistically significant positive relation to supply in the life insurance market. Another financial factor was investigated by Deyganto \& Alemu (2019). The authors studied the factors affecting financial performance of insurers and noted that underwriting, premium growth, solvency ratio, growth rate of GDP, and inflation rate have significant effect on financial performance of the insurance companies. In addition, reinsurance dependence, company size and interest rate have no significant effect on financial performance.

However, Blanchet (2007) investigated the impact of changing life cycles on insurance and noted and examined how far such a claim is valid, shortly reviewing fields such as potential economic growth, financial markets, pensions, the demand for additional old age income insurance, health and old age invalidity. Studying the life insurance demand Shahriari \& Shahriari (2016) illustrated that it is influenced by various economic (age, saving) and social and demographic (education, marital, income) factors.

But it is the most important for our research to study the international experience of the impact of health status and mortality factors on insurance market competitiveness. In addition, a lot of world recognized scientists investigates different aspects of the relationship between mortality and life insurance efficiency and competitiveness as follows:

i) effects of health status on life insurance among three health status indicators: selfperceived health status; objective health status; future health risk (Tsendsuren et al., 2018);

ii) stochastic mortality in life insurance, market reserves and mortality-linked insurance contracts (Dahl, 2004); 
iii) annual changes in mortality rates and related effects on life insurance company financials (Santos et al., 2017);

iv) impact of mortality risk on the asset and liability management of insurance companies (Ming, 2013);

v) macroeconomic risks and life insurer solvency (Hanewald et al., 2011);

vi) mortality risk prediction (Sijbrands et al., 2009);

vii) analyze the individual life insurance mortality trends - cause of death impact (Serykh \& Yang, 2019).

Additionally, at least one study is the closest to our investigation. Its research paper was the first in a series that deeply analyzes U.S. population mortality trends by cause of death and its relationship to the individual life insurance population. The research results show that when actuaries review mortality improvement experience and set future mortality improvement assumptions, it is important to take the cause of death prevalence into consideration (Serykh \& Yang, 2019).

\subsection{The relationship between the causes of death and life insurance market competitiveness: case study of Ukraine}

As we described before, applying genetic testing technologies in insurance can create a lot of benefits for improving, firstly - risk assessment in life and health insurance, and, secondly health care system, because genetic technologies system promotes and supports early detection diseases, and increases the efficiency of treatment of diseases, etc.). In addition, using genetic testing as underwriting method can have a lot of advantages for non-EU countries as whole, and also its insurance market. Furthermore, we strong believe, that estimation of the influence of mortality factors on life insurance related to genetic testing technologies as a risk assessment method in insurance. Thus, this part of our research has provided the empirical results of assessing the interconnection between the causes of death and life insurance market competitiveness in the context of Ukrainian insurance market (as a case study of European country that is not member of the EU). Besides, among the research papers about insurance market in Ukraine there are many scientists who investigates the factors impact on the life insurance industry. Thus, Rud \& Kondratska (2019), Prystupa et al. (2019), Zolotar'ova \& Galaganov (2017) studies the modern trends, problems and prospects for Ukrainian life insurance market development. Kryvytska 
(2019), Derkach (2012) and Savras \& Yurynets (2014) has investigated the life insurance market factors and general trends using correlation analysis. But, today there isn't any research papers about the impact estimation of causes of death on the Ukrainian life insurance market competitiveness.

\subsubsection{Analysis of the insurance market in Ukraine.}

To increase the objectivity and scientific validity of the research of the impact of death causes on the insurance market, we consider it advisable to start an analysis of the general trends in the development of the insurance market of Ukraine on such four indicators as the share of the entire insurance market of the country in gross domestic product $\left(\eta_{\text {Total }}\right)$; share of life insurance market in the structure of the entire insurance market of the country $\left(\eta_{L i f e}\right)$; as well as country insurance coverage rates $\left(\gamma_{\text {Total }}\right)$ and the life insurance market $\left(\gamma_{\text {Life }}\right)$. The estimated values of the above indicators for 2005-2018 are presented in Fig. 1.

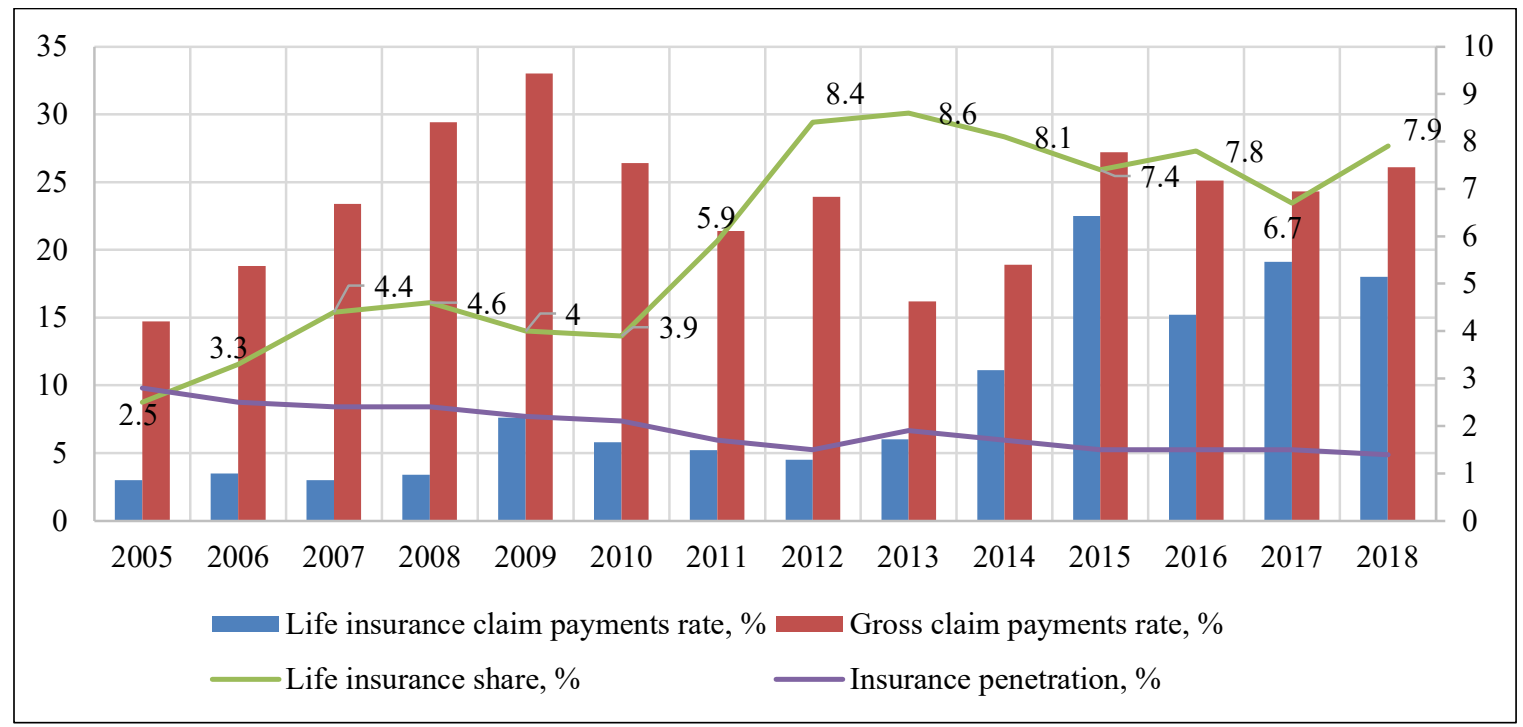

Fig. 1 - The indicators of the insurance claim payments rates (left scale), life insurance market share and insurance penetration (right scale).

Source: Authors' research results. 
The four indicators are designed to analyze the general trends in the development of both the insurance market of the country as a whole and the market of life insurance in particular. One of the main goals of the article is to investigate the impact of deaths causes on the life insurance market, since "death" as a risk is a mandatory feature in the life insurance market. One of the main indicators characterizing the role of the insurance market in the country's economy is the share of the insurance market in GDP $\left(\eta_{\text {Total }}\right)$, which is calculated according to the formula (1). Thus, during the 2005-2018 period, the share of the country's insurance market in GDP tended to decline from $2.8 \%$ (2005) to $1.4 \%$ (2018), which are the maximum and minimum values for the index during the period of the research. However, the share of the life insurance market in the structure of the entire country's insurance market $\left(\eta_{\text {Life }}\right)$, on the contrary, has increased: from $2.5 \%$ in 2005 , which is also the minimum in $2005-2018$, to $7.9 \%$ in 2018 . At the same time, the share of the life insurance market reached its maximum in 2013: $\eta_{\text {Life }}=8,6 \%$.

The next two indicators in Fig. 1 in accordance with formulas (3) and (4) characterize the level of payments in the total insurance market of the country, that is, together in the life and nonlife insurance markets $\left(\gamma_{\text {Total }}\right)$, as well as the rate of payout in the life insurance market alone $\left(\gamma_{\text {Life }}\right)$. Overall, over the 2005-2018 survey, the above indicators tended to increase the share of insurance premiums relative to insurance premiums. Thus, the level of payments in the Ukrainian total insurance market increased from $14.7 \%$ in 2005 , which is also the minimum value of this indicator for the $2005-2018$, to $26.1 \%$ in 2018 . However, the maximum value of $\gamma_{\text {Total }}$ within the study period was fixed in $2009, \gamma_{\text {Total }}=33,0 \%$.

Claim payments rates at the life insurance market $\left(\gamma_{\text {Life }}\right)$ was increasing even faster in 20052018. Thus, at the beginning of the study period and in 2007. $\gamma_{\text {Life }}=3,0 \%$, which are the minimum values of this payout indicator. The maximum value $\gamma_{L i f e}=22,5 \%$ was in 2015 , and in 2018 , the indicator has decreased: $\gamma_{\text {Life }}=18,0 \%$.

\subsubsection{Analysis of the general trends of death causes in Ukraine}

Since the risk of death is one of the main subjects of insurance in the life insurance market, we consider it appropriate to increase the scientific validity of our study by estimating the general trends in the number of deaths depending on the causes of death. 
We analyzed the dynamics of the total number of deaths in the country from all death causes (indicator X1). The dynamics of the number of deaths from each of the nineteen major groups of causes of death (X2-X20) by international standards for the classification of death causes were also examined. Additionally, the specific proportions of these indicators in the total number of all dead (X1) were analyzed, which corresponds to the index $\mathrm{SD}_{\mathrm{n}}$ of formula (5), as well as other indicators.

The results of data analysis for the years 2005-2018 show that all nineteen death causes (X2$\mathrm{X} 20$ ), depending on their proportion $\mathrm{SD}_{\mathrm{n}}$ in the total number of all $\mathrm{X} 1$ deaths, could be divided into several groups. The criteria we have developed for each of the groups for the proportion of death cause in their total number are shown in Table 2.

Tab. 2 - Classification of groups of death causes according to their proportion*

\begin{tabular}{|c|l|l|}
\hline № & \multicolumn{1}{|c|}{ The list of the groups } & \multicolumn{1}{c|}{ Criteria for inclusion of indicators in groups 1-4 } \\
\hline 1 & First group & $0,00 \leq \mathrm{SD}_{n} \leq 0,10$ \\
\hline 2 & Second group & $0,10<\mathrm{SD}_{n} \leq 1,00$ \\
\hline 3 & Third group & $1,00<\mathrm{SD}_{n} \leq 10,00$ \\
\hline 4 & Fourth group & $\mathrm{SD}_{n} \geq 10,00$ \\
\hline
\end{tabular}

Source: Authors' research results.

The division of groups of death causes based on the proposed criteria is made according to the author's approach, which is based on the current state and dynamics of changes in the proportion of death causes in their overall structure. For more information on the proportions of death causes, including their limiting and arithmetic mean values for the years 2005-2018, see Table 3.

Tab. 3 - The limit and the arithmetic values of the shares of death via causes of death for the years 2005-2018 in Ukraine

\begin{tabular}{|c|c|c|c|c|c|}
\hline \multirow{2}{*}{$\begin{array}{c}\text { Causes of } \\
\text { death } \\
\mathbf{X}_{\mathbf{n}}\end{array}$} & \multicolumn{5}{|c|}{ Shares of death via causes of death $\mathbf{S D}_{\boldsymbol{n}}$} \\
\cline { 2 - 6 } & \multicolumn{2}{|c|}{ Min } & \multicolumn{2}{c|}{ Max } & $\begin{array}{c}\text { Average for } \\
\mathbf{2 0 0 5}-2018\end{array}$ \\
\cline { 2 - 6 } & value & year & value & year & \\
\hline $\mathrm{X} 2$ & 1,52 & 2017 & 2,29 & 2008 & 1.95 \\
\hline $\mathrm{X} 3$ & 11,75 & 2005 & 14,01 & 2012 & 12.93 \\
\hline $\mathrm{X} 4$ & 0,04 & All the rest & 0,05 & $2005,2007,2011$ & 0.04 \\
\hline $\mathrm{X} 5$ & 0,35 & 2014 & 0,44 & 2005 & 0.38 \\
\hline
\end{tabular}




\begin{tabular}{|c|c|c|c|c|c|}
\hline X6 & 0,19 & 2016,2017 & 0,43 & 2005 & 0.28 \\
\hline X7 & 0,80 & 2018 & 0,97 & 2008 & 0.87 \\
\hline X8 & 0,00 & All & 0,00 & All & 0.00 \\
\hline X9 & 0,00 & 2016,2017 & 0,01 & All the rest & 0.01 \\
\hline X10 & 62,51 & 2005 & 68,02 & 2015 & 65.66 \\
\hline X11 & 2,12 & 2017 & 3,58 & 2005 & 2.73 \\
\hline X12 & 3,77 & 2016 & 4,66 & 2008 & 4.07 \\
\hline X13 & 0,06 & 2009,2010 & 0,09 & 2012,2018 & 0.07 \\
\hline X14 & 0,08 & $2014-2018$ & 0,10 & $2005,2006,2008$ & 0.09 \\
\hline X15 & 0,41 & 2016 & 0,48 & 2012 & 0.44 \\
\hline X16 & 0,01 & All the rest & 0,02 & 2009,2010 & 0.01 \\
\hline X17 & 0,22 & 2018 & 0,36 & 2009 & 0.30 \\
\hline X18 & 0,21 & 2018 & 0,29 & $2006,2007,2011$ & 0.26 \\
\hline X19 & 2,07 & 2013 & 4,27 & 2018 & 3.16 \\
\hline X20 & 5,26 & 2018 & 8,95 & 2005 & 6.75 \\
\hline
\end{tabular}

Source: Authors' research results.

Dynamics information for the years 2005-2018 for the TOP 3 causes of death depending on their share in the structure of all deaths, as well as the share of all deaths in the population structure (mortality rate) are shown in Fig. 2.

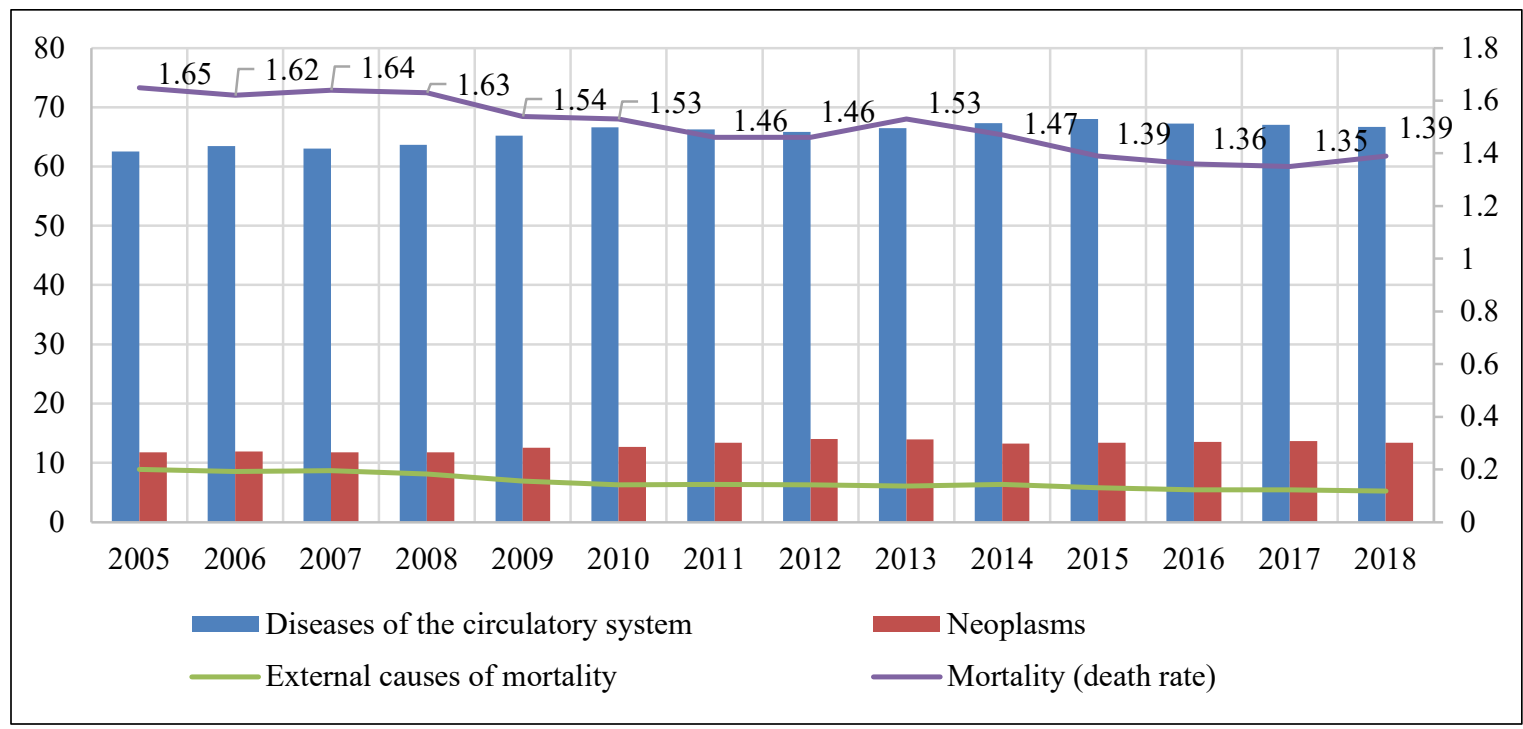

Fig. 2 - The dynamics of the three largest via share of causes of death (left scale) and the mortality (death rate) in Ukraine for the years 2005-2018.

Source: Authors' research results. 
Figure 2 states that the share of deaths from "Diseases of the circulatory system" and from "Neoplasms" have a general upward trend over the 2005-2018 study period. Also, it should be noted that the dynamics of the total death rate shows a downward trend.

\subsubsection{The interconnection between the causes of death and life insurance market} competitiveness.

Studying the relationship between the life insurance and causes of death we are going to define as follows:

i) the interconnection between the causes of death and life insurance market competitiveness via the calculations of the Pearson correlation coefficient (r), and determination coefficient $\left(\mathbf{r}^{2}\right)$;

ii) whether or not there is a statistically significant impact of causes of death on life insurance market via defining the one-factor regression model $(\mathrm{Y}=\mathrm{A}+\mathrm{BX}$, where $\mathrm{Y}-$ dependent variable (Y1, Y2), X - independent variable (X1-X20); A and B - regression coefficients), and via calculations of the Student's t-criterion ( $\mathrm{tst}_{\mathrm{st}}$ ); critical value of the Student's t-criterion for a given degrees of freedom $\left(\mathrm{t}_{\mathrm{cr}}\right)$; average approximation error (Error); statistical level of indicators dependence ( $\mathrm{D}$, significant or insignificant); P-value.

Furthermore, for assessment the level of statistically significant impact of causes of death on life insurance market we put forward and justified a null (H0) and alternative hypotheses (H1$\mathrm{H} 40$ ). Thus, according to the $\mathrm{HO}$ - there isn't any statistically significant impact of independent variables on dependent variables.

Thus, our alternative hypotheses that were tested can be described as follow below:

i) according to the $\mathrm{Y} 1=T G P_{\text {Life }}$ : cause of deaths (by number of deaths, including by the causes of death) has statistically significant inversely proportional impact on life insurance market premiums (hypotheses $\mathrm{H} 1-\mathrm{H} 20$ );

ii) according to the $\mathrm{Y} 2=G C P_{\text {Life }}$ : cause of deaths (by number of deaths, including by the causes of death) has statistically significant direct proportional impact on gross claim payments of the life insurance market (hypotheses $\mathrm{H} 21-\mathrm{H} 40$ ).

The results of testing of the hypotheses are presented in Table 4 . 
Tab. 4 - The characteristics of the research hypotheses and correlation and regression results

\begin{tabular}{|c|c|c|c|c|c|c|c|c|}
\hline \multicolumn{4}{|c|}{ Description of the alternative hypotheses } & \multirow{2}{*}{\multicolumn{2}{|c|}{$\begin{array}{c}\begin{array}{c}\text { Correlation } \\
\text { results }\end{array} \\
\end{array}$}} & \multirow{2}{*}{\multicolumn{3}{|c|}{ Regression indicators }} \\
\hline & & ariables & & & & & & \\
\hline № & $\mathbf{X n}$ & $\begin{array}{c}\mathrm{Y} 1= \\
T G P_{\text {Life }} ; \\
\mathrm{Y} 2=G C P_{\text {Life }}\end{array}$ & $\begin{array}{l}\text { Influence } \\
\text { of X on Y }\end{array}$ & $\mathbf{r}$ & $\mathbf{r}^{2}$ & $\mathbf{t s t}_{\mathbf{s t}}$ & P-value & $\begin{array}{l}\text { Error, } \\
\quad \%\end{array}$ \\
\hline H1 & \multirow{2}{*}{$\mathrm{X} 1$} & Y1 & Inversely & -0.899 & 0.808 & -7.108 & 0.000020 & 25.1 \\
\hline H21 & & Y2 & Directly & -0.871 & 0.759 & -6.142 & 0.000073 & 189.7 \\
\hline H2 & \multirow{2}{*}{$\mathrm{X} 2$} & Y1 & Inversely & -0.910 & 0.828 & -7.609 & 0.000010 & 29.6 \\
\hline H22 & & $\mathrm{Y} 2$ & Directly & -0.921 & 0.848 & -8.193 & 0.000005 & 130.3 \\
\hline H3 & \multirow{2}{*}{$\mathrm{X} 3$} & Y1 & Inversely & -0.737 & 0.543 & -3.781 & 0.003042 & 53.0 \\
\hline $\mathrm{H} 23$ & & $\mathrm{Y} 2$ & Directly & -0.919 & 0.844 & -8.067 & 0.000006 & 100.1 \\
\hline H4 & \multirow{2}{*}{$\mathrm{X} 4$} & Y1 & Inversely & -0.910 & 0.829 & -7.564 & 0.000011 & 34.7 \\
\hline $\mathrm{H24}$ & & $\mathrm{Y} 2$ & Directly & -0.803 & 0.645 & -4.669 & 0.000684 & 218.7 \\
\hline H5 & \multirow{2}{*}{$\mathrm{X} 5$} & Y1 & Inversely & -0.852 & 0.727 & -5.647 & 0.000149 & 34.9 \\
\hline H25 & & $\mathrm{Y} 2$ & Directly & -0.754 & 0.569 & -3.977 & 0.002170 & 245.7 \\
\hline H6 & \multirow{2}{*}{ X6 } & $\mathrm{Y} 1$ & Inversely & -0.794 & 0.630 & -4.524 & 0.000867 & 40.4 \\
\hline H26 & & $\mathrm{Y} 2$ & Directly & -0.701 & 0.491 & -3.406 & 0.005863 & 200.8 \\
\hline H7 & \multirow{2}{*}{$\mathrm{X} 7$} & Y1 & Inversely & -0.852 & 0.725 & -5.628 & 0.000154 & 48.2 \\
\hline H27 & & $\mathrm{Y} 2$ & Directly & -0.899 & 0.808 & -7.115 & 0.000020 & 138.8 \\
\hline H8 & \multirow{2}{*}{$\mathrm{X} 8$} & Y1 & Inversely & 0.111 & 0.012 & -0.512 & 0.618825 & 97.4 \\
\hline $\mathrm{H28}$ & & $\mathrm{Y} 2$ & Directly & -0.193 & 0.051 & -0.802 & 0.439386 & 414.7 \\
\hline H9 & \multirow{2}{*}{ X9 } & Y1 & Inversely & -0.641 & 0.411 & -2.893 & 0.014622 & 59.5 \\
\hline H29 & & Y2 & Directly & -0.575 & 0.331 & -2.434 & 0.033173 & 260.1 \\
\hline H10 & \multirow{2}{*}{ X10 } & Y1 & Inversely & -0.918 & 0.843 & -8.024 & 0.000006 & 23.0 \\
\hline H30 & & $\mathrm{Y} 2$ & Directly & -0.912 & 0.831 & -7.680 & 0.000010 & 145.3 \\
\hline H11 & \multirow{2}{*}{ X11 } & Y1 & Inversely & -0.897 & 0.804 & -7.027 & 0.000022 & 32.2 \\
\hline H31 & & Y2 & Directly & -0.812 & 0.659 & -4.816 & 0.000540 & 218.2 \\
\hline H12 & \multirow{2}{*}{$\mathrm{X} 12$} & Y1 & Inversely & -0.729 & 0.531 & -3.684 & 0.003603 & 55.6 \\
\hline H32 & & Y2 & Directly & -0.760 & 0.577 & -4.050 & 0.001917 & 174.3 \\
\hline H13 & \multirow{2}{*}{ X13 } & Y1 & Inversely & -0.145 & 0.021 & -0.506 & 0.622574 & 90.8 \\
\hline H33 & & Y2 & Directly & -0.231 & 0.053 & -0.822 & 0.428393 & 336.4 \\
\hline H14 & \multirow{2}{*}{ X14 } & Y1 & Inversely & -0.914 & 0.836 & -7.836 & 0.000008 & 21.2 \\
\hline H34 & & Y2 & Directly & -0.876 & 0.767 & -6.291 & 0.000059 & 187.5 \\
\hline H15 & \multirow{2}{*}{ X15 } & $\mathrm{Y} 1$ & Inversely & -0.842 & 0.709 & -5.407 & 0.000214 & 33.3 \\
\hline H35 & & $\mathrm{Y} 2$ & Directly & -0.864 & 0.747 & -5.952 & 0.000096 & 197.3 \\
\hline H16 & \multirow{2}{*}{ X16 } & $\mathrm{Y} 1$ & Inversely & -0.743 & 0.553 & -3.850 & 0.002701 & 73.1 \\
\hline H36 & & Y2 & Directly & -0.736 & 0.541 & -3.759 & 0.003159 & 345.4 \\
\hline H17 & \multirow{2}{*}{ X17 } & $\mathrm{Y} 1$ & Inversely & -0.680 & 0.462 & -3.210 & 0.008310 & 79.4 \\
\hline H37 & & $\mathrm{Y} 2$ & Directly & -0.821 & 0.674 & -4.982 & 0.000414 & 385.0 \\
\hline H18 & \multirow{2}{*}{ X18 } & Y1 & Inversely & -0.939 & 0.881 & -9.423 & 0.000001 & 26.5 \\
\hline H38 & & Y2 & Directly & -0.938 & 0.880 & -9.374 & 0.000001 & 129.8 \\
\hline H19 & \multirow{2}{*}{ X19 } & $\mathrm{Y} 1$ & Inversely & -0.421 & 0.177 & -1.608 & 0.136184 & 61.1 \\
\hline H39 & & $\mathrm{Y} 2$ & Directly & -0.197 & 0.039 & -0.695 & 0.501226 & 306.2 \\
\hline H20 & \multirow{2}{*}{$\mathrm{X} 20$} & $\mathrm{Y} 1$ & Inversely & -0.860 & 0.739 & -5.831 & 0.000114 & 33.7 \\
\hline H40 & & Y2 & Directly & -0.775 & 0.600 & -4.246 & 0.001375 & 224.1 \\
\hline
\end{tabular}

Source: Authors' research results. 
According to table 4, the results of correlation and determination coefficient's show that almost for all alternative hypotheses (except H8, H28, H13, H19, H33, H39) are related the high level of statistically inversely proportional relationship (interconnections) between $\mathrm{X}$ and $\mathrm{Y}$ because almost all determined values of Pearson correlation coefficient (r) are negative and high.

In addition, according the regression calculations $\mathrm{t}_{\mathrm{cr}}=2.179$, hence $\mathrm{t}_{\mathrm{St}}<\mathrm{t}_{\mathrm{cr}}$, so there are no reasons to reject the null hypotheses and that's why the null hypotheses are accepted (Malyovanyi et al., 2018). Additionally, according to these regression results the relationship between indicators in the regression are statistically insignificant. Furthermore, the values of average approximation error (Error) states that adequacy of the regression models for all alternative hypotheses H1-H40 is low, because the average approximation errors are more than $15,0 \%$. Thus, is not necessary to show and analyze the regression equations.

\subsection{The system (model) of development and using the genetic testing in insurance.}

In the context of genetic testing in insurance implications for non-EU insurance markets as a part of the European integration process this research paper has defined the development and interaction model of the human genetics and insurance. The mechanism of the model describes the interaction features through three main parts. In addition, the literature review shows that social and ethical aspects and issues of human genetics and insurance are still developing because of few preconditions, and that is why the research results make it possible to create some conclusions and contributions to the area.

All these elements of the model have evidence-based justifications for the ethical and social aspects of human genetics and insurance, and are presented in the Fig. 3 through the following items: genetic discrimination and information asymmetry problems; historical background; human rights protection against genetic discrimination in insurance peculiarities. It is important to analyze these peculiarities as a part of future applying genetic testing technologies in insurance implications for non-EU and European Union insurance markets where there is not any specific government regulation in this area. 


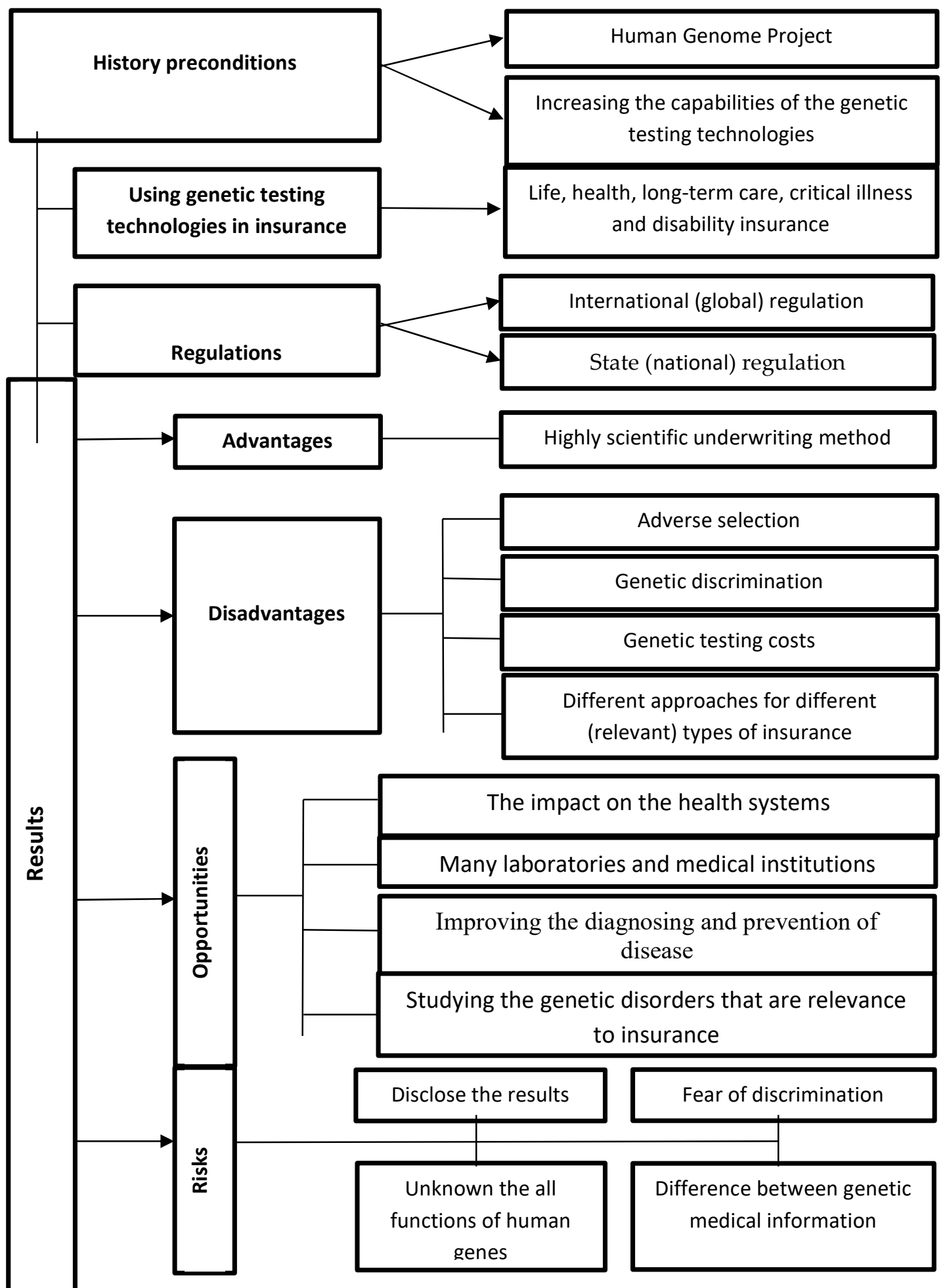

Fig. 3 - The system (model) of development and using the genetic testing technologies in Source: authors' own research results. 
As you can see in Fig. 3, the human genetics and insurance interconnection can be described as system (model) of development and using the genetic testing technologies in insurance. The analysis shows that the most important history preconditions of the using the genetic testing results in insurance were the Human Genome Project and high-level genetic testing technologies. And the last one was one of the main advantages because it was stimulating the genetic testing development as a new underwriting method. There are a lot of other advantages and opportunities, and also disadvantages and risks.

The suggested model has described the factors, terms, conditions, peculiarities and principles of the using and the justification the genetic testing as a part of insurance process.

Today the world experience of the insurance market activity shows the using genetic testing results and information in underwriting. Additionally, the research study results indicate the advantages, disadvantages, opportunities and risks for all parts (subjects) of using genetic testing in life, health, long-term care, critical illness and disability insurance.

Altogether, comprehensive analysis the components of the suggested system (model) of development and using the genetic testing in insurance are provided and described in the next sections of this research paper.

\section{Conclusions}

Our paper has provided new evidence which have argued why it is importantly to implement genetic testing technologies as a new underwriting tool for non-EU countries where there is not any specific this kind of insurance market regulations as a part of the European integration process as follows below.

Firstly, the results of literature review indicate that not every European country has highlydevelopment genetic testing in insurance government regulations and only Austria, Belgium, Denmark, Finland, Germany, Netherlands, Norway, Switzerland, etc., there is detailed management approaches that define of using genetic for insurance purposes. Furthermore, applying genetic testing technologies have a lot of benefits for risk assessment in insurance and for improving health care system (early detection diseases, increase the treatment of diseases, etc.). That's why, we strongly recommend to use legally this underwriting tool (genetic testing) for insurance purposes for European countries without any specific regulations in this area. 
Secondly, despite the international regulations and human rights protection legislation, using genetic testing for insurance purposes often involves genetic discrimination. However, applying genetic technologies in insurance makes the risk assessment more effective, that also could be a positive change for improving health care system. Also, the research revealed that the factors influencing the insurance market can be very different, for example: general, health status and mortality factors.

Thirdly, our paper has provided new evidence that the interconnections between causes of death and life insurance market are related the high level of statistically inversely proportional relationship (interconnections) because of the results of correlation-regression analysis almost for all study cases. In addition, the analysis shows that health status and mortality factors have a big influence on life insurance market, and therefore it is important to conduct a detailed study in this area. Furthermore, this finding suggests that for 34 of 40 alternative hypotheses are related the high level of statistically inversely proportional relationship (interconnections) between our research indicators. And there are no reasons to reject the null hypotheses and that's why the null hypotheses are accepted.

Fourth, our research study defined the system (model) of development and using of genetic testing technologies in insurance as a part of genetic testing in insurance implications for nonEuropean Union insurance markets in the context of the EU integration process. The part of this model describes the history preconditions that involve the Human Genome Project and other scientific knowledge that increases the opportunity of using genetic testing technologies as the underwriting tool. Secondly, these are the results of the human genetics and insurance implications as follow below: advantages, disadvantages, opportunities and risks. And, finally, its regulations (international and by the countries) that protect human rights against genetic discrimination in insurance.

And fifth, the results of this research make it possible to identify the following future research directions in the context of genetic testing in insurance implications for non-EU insurance markets as a part of the European integration process: firstly, analysis of the disadvantages and ethical, social consequences for society and insurance market as a result of applying genetic technologies in underwriting; secondly, a correlation-regression analysis of the relationship between the number of sick persons (depending on the type of illness) and the financial indicators 
of the insurance market as a whole and the life insurance market in particular as a part of genetic testing in insurance implications for non-EU insurance markets.

Altogether, this study sheds light on a rather underexplored research area, that will be very useful in the context of future applying genetic testing as underwriting tool in insurance because genetics is also a modern and highly effective method for disease detection, diagnosis and treatment.

\section{References}

1. Andrews, L. (1987). Medical Genetics: A Legal Frontier. American Bar Foundation, Chicago, IL.

2. Arych, M., Levon, M. (2019). The use of genetic testing in life and health insurance. Finance of Ukraine. № 3: 118-128. Available at: http://finukr.org.ua/?page_id=774\&lang=en\&aid=4599

3. Barlow-Stewart, K., Liepins, M., Doble, A., Otlowski, M. (2018). How are genetic test results being used by Australian life insurers? European Journal of Human Genetics, 26, pp. $1248-1256$.

4. Berezianko, T. (2018). Problems of innovative development of the system of Ukraine. Ukrainian Journal of Food Science, 6(2), pp. 246-255.

5. Bikker, J., \& Popescu, A. (2014). Efficiency and competition in the Dutch non-life insurance industry. Discussion PaperSeries, pp. 14-12.

6. Blanchet, D. (2007). Changing Life Cycles and their Impact on Insurance. The Geneva Papers, 32, pp. 1-10.

7. Boyer-Kassem, T., Duchene, S., and Engelen, B. (2017). On Discrimination in Health Insurance. GREDEG WP No. 2017-23.

8. Buric, M., Bacovic, M., Cerovic, J. and Lipovina Bozovic, M. (2017). Factors Influencing Life Insurance Market Development in Montenegro. Periodica Polytechnica Social and Management Sciences, 25(2), pp. 141-149.

9. Chizoba, P. et al. (2018). Effect of Inflation Rate on Insurance Penetration of Nigerian Insurance Industry. International Research Journal of Finance and Economics, 170, 66-76. 
10. Ćurak, M., Džaja, I. and Pepur, S. (2013). The Effect of Social and Demographic Factors on Life Insurance Demand in Croatia. International Journal of Business and Social Science, Vol. 4 No. 9, pp. 65-72.

11. Daare, W.J. (2016). Factors affecting general insurance company's profitability: empirical study in India. International Journal Of Marketing, Financial Services \& Management Research, Vol.5 (12), pp. 1-8.

12. Dahl, M. (2004). Stochastic mortality in life insurance: market reserves and mortalitylinked insurance contracts. Insurance: Mathematics and Economics, 35, pp.113-136.

13. Dalpé, G., Ngueng Feze, I., Salman, S., Joly, Y., Hagan, J., Lévesque, E., Dorval, V., Blouin-Bougie, J., Amara, N., Dorval, M., Simard, J. (2017). Breast Cancer Risk Estimation and Personal Insurance: A Qualitative Study Presenting Perspectives from Canadian Patients and Decision Makers. Frontiers in Genetics, Volume 8, Article 128, doi: $10.3389 /$ fgene. 2017.00128

14. Das, S., \& Shome, M.K. (2016). A study on determinants of insurance penetration in the context of India. International Journal of Marketing and Human Resource Management (IJMHRM), Volume 7, Issue 3, pp. 85-94.

15. Derkach, O. (2012). Factors impact on the financial security of the insurance market. Business-Inform, № 6, pp.187-90.

16. Deyganto, K.O. \& Alemu, A.A. (2019). Factors Affecting Financial Performance of Insurance Companies Operating in Hawassa City Administration, Ethiopia. Universal Journal of Accounting and Finance, 7(1). pp. 1-10.

17. Durnin, M., Hoy, M., Ruse, M. (2012). Genetic Testing and Insurance: The Complexity of Adverse Selection. DISCUSSION PAPER, University of Guelph.

18. Fagart, M.C. et al. (2002). Risk Mutualization and Competition in Insurance Markets. The Geneva Risk and Insurance Review. doi: 10.1023/A:1021948826240

19. Gemmo, I. \& Götz, M. (2016). Life insurance and demographic change: An empirical analysis of surrender decisions based on panel data. ICIR Working Paper Series, No. 24/16, Goethe University Frankfurt, International Center for Insurance Regulation (ICIR), Frankfurt a. M.

20. Genetic screening ethical issues (1993). Nuffield Council on Bioethics, London WC1B $3 E G$. 
21. Goel, Shivam (2018). Genetic Discrimination \& Health Insurance: An Analysis. Electronic copy available at: https://ssrn.com/abstract $=3153391$, (accessed 22 December 2019).

22. Grmanová, E., \& Strunz, H. (2017). Efficiency of insurance companies: Application of DEA and Tobit analyses. Journal of International Studies, 10(3), pp. 250-263.

23. Hanewald, K., Post, T. \& Gründl, H. (2011). Stochastic Mortality, Macroeconomic Risks and Life Insurer Solvency. The Geneva Papers, 36, pp. 458-475.

24. Health Plan Landscape for Genetic Testing (2018), AHIP. Available at: https://www.ahip.org/, (accessed 06 June 2019).

25. Imanberdiev, B., Cherep, A., Cherep, O., \& Mostenska, T. (2018). Peculiar features of business incubators functioning: Ukrainian and world experience. Ukrainian Food Journal, 7(2), pp. 324-336.

26. Jean-Christophe Bélisle-Pipon, Effy Vayena, Robert C. Green, and I. Glenn Cohen (2019). Genetic testing, insurance discrimination and medical research: what the United States can learn from peer countries. Nature medicine, 25, pp.1198-1204.

27. Klein, Ronald (2017). Genetics and Life Insurance. A View Into the Microscope of Regulation. Published by The Geneva Association-International Association for the Study of Insurance Economics.

28. Knoppers, B. \& Joly, Y. (2004). Physicians, genetics and life insurance. CMAJ. APR. 27, $170(9), 1421-1423$.

29. Kryvytska, O. (2019). Evaluation of Life Insurance Companies Using Correlation Analysis. Business-Inform, № 5, pp.162-168. (Original work written in Ukrainian).

30. Lane M., Feze, I. N., Joly, Y. (2015). Genetics and Personal Insurance: the Perspectives of Canadian Cancer Genetic Counselors. J Genet Counsel, 24:1022-1036. doi: 10.1007/s10897015-9841-9

31. Lemmens T., Joly Y., Knoppers B.M. (2004). Genetic and life insurance: a comparative analysis. GenEdit 2004; Available at https://www.researchgate.net/publication/ 27556127, (accessed 03 November 2018).

32. Lombardo, Mark (2018). The Impact of Genetic Testing on Life Insurance Mortality. Munich Re. Society of Actuaries (SOA). 
33. Malyovanyi, M., Nepochatenko, O., Nesterchuk, Y. (2018). Conceptual Approaches to Improving the Functioning of Non-state Social Insurance Institutions in Ukraine. Economics \& Sociology, 11(2), pp. 289-304.

34. McEwen, J.E., McCarty, K., Reilly, P.R. (1992). A Survey of State Insurance Commissioners Concerning Genetic Testing and Life Insurance. Am. J. Hum. Genet., 51:785792.

35. McEwen, J.E., McCarty, K., Reilly, P.R. (1993). A Survey of Medical Directors of Life Insurance Companies Concerning Use of Genetic Information. Am. J. Hum. Genet, 53:33-45. 36. Ming, Q. (2013). The Impact of Mortality Risk on the Asset and Liability Management of Insurance Companies. Asia-Pacific Journal of Risk and Insurance, De Gruyter, Vol. 7(2), pp. 81-104.

37. Nabholz, C.E. (2011), Fair risk assessment in life and health insurance. Swiss Reinsurance Company Ltd.

38. Nabholz, C.E. (2016), Seeing the future? How genetic testing will impact life insurance. Swiss Re Centre for Global Dialogue.

39. National Commission for the State Regulation of Financial Services Markets in Ukraine. Official site. Available at: http://www.nfp.gov.ua/, (accessed 22 February 2019).

40. Newson, A.J., Ayres, S., Boyle, J., Gabbett, M.T., Nisselle, A. (2018). Human Genetics Society of Australasia Position Statement: Genetic Testing and Personal Insurance Products in Australia. Twin Research and Human Genetics, Volume 21, Number 6, pp. 533-537.

41. Nicholls, S.G., Joly, Y., Moher, E., Little, J. (2014). Genetic discrimination and insurance in Canada: Where are we now? On The Risk. 30(3): 46-52.

42. Office of the Privacy Commissioner of Canada (2012), Genetic Information, the Life and Health Insurance Industry and the Protection of Personal Information: Framing the Debate. 43. Pokorski, R. (1991). Genetic Screening and the Insurance Industry. The Yale Journal of Biology and Medicine, 64, pp. 53-57.

44. Pokorski, R. J. (1997). Insurance Underwriting in the Genetic Era. Am. J. Hum. Genet., 60:205-216.

45. Press Release, National Human Genome Research Inst., International Consortium Completes Human Genome Project (Apr. 14, 2003), Available at http://www.genome.gov/11006929, (accessed 25 January 2019). 
46. Prince, A. (2016). Tantamount to Fraud?: Exploring Non-Disclosure of Genetic Information in Life Insurance Applications as Grounds for Policy Rescission. Health Matrix: The Journal of Law-Medicine, Volume 26, Issue 1.

47. Priyan, V. \& Selvakumar, M. (2012). Factors Influencing the Life Insurance Product Determination. Vishwakarma Business Review, Volume II, Issue 2, pp. 49-54.

48. Prystupa, L., Smalyuk, T., Sovyak, I. (2019). Life Insurance: Modern Trends and Prospects in Ukraine. Prychornomors'ki ekonomichni studiyi (Black Sea Economic Studies), № 6, pp.230-234. (Original work written in Ukrainian).

49. Raišienè, A.G. \& Morkūnas, M. (2018). Towards Healthier Life: Changes in growing of health-friendly food crops and products in Lithuania before accession to EU and after. Ukrainian Food Journal, 7(2), pp. 337-351.

50. Rakshit, D. (2017). Analysis of growth of insurance density and insurance penetration in India after initiation of reforms in insurance sector. International Journal of Research in Economics and Social Sciences (IJRESS), 7(6), pp. 64-171.

51. Riba, S.R. (2017). The Use of Genetic Information in Health Insurance: Who will be Helped, Who will be Harmed and Possible Long-Term Effects. Review of law and justice genetic information in health insurance, Vol.16:2.

52. Rothstein, M.A., Joly, Y. (2009). Genetic information and insurance underwriting: contemporary issues and approaches in the global economy insurance. In The Handbook of Genetics and Society: Mapping the New Genomic Era. Edited by: Atkinson P, Glasner P, Lock M. London: Routledge:127-144.

53. Rud, I. \& Kondratska, K. (2019). Ukraine's Insurance Market: Analysis and Prospects for Development. Naukovyy visnyk Uzhhorods'koho natsional'noho universytetu (Scientific Bulletin of Uzhgorod National University), Volume 23, Part 2, pp.87-91. (Original work written in Ukrainian).

54. Santos, M. et al. (2017). Annual Changes in Mortality Rates and Related Effects on Life Insurance Company Financials. John.Journal of Applied Financial Research; Gulfport, Vol. 1, pp. 61-73.

55. Savras, I. \& Yurynets, R. (2014). Investigation of Life Insurance Markets in Ukraine by Means of Cross-Correlation Regressive Analysis. Collection of scientific works "Efficacy public administration”, Issue 41, pp. 303-309. 
56. Serykh, N. \& Yang, A. (2019). Analyzing Individual Life Insurance Mortality Trends Cause of Death Impact. Munich American Reassurance Company, Atlanta, Georgia.

57. Shahriari, S. \& Shahriari, M. (2016). The Effect of Social and Demographic and Economic Factors on Life Insurance Demand. International Journal of Management and Social Science Research Review, Vol.1, Issue 28, pp. 200-207.

58. Shawar, K. \& Siddiqui, D.A. (2019). Factors Affecting Financial Performance of Insurance Industry in Pakistan. Research Journal of Finance and Accounting, 10(5), pp. 29-41.

59. Shirinyan, L. (2014). Financial regulation of insurance industry of Ukraine: theory and practice problems. Center for Educational Literature. (Original work written in Ukrainian). 60. Sijbrands, E.J., Tornij, E., Homsma, S.J. (2009). Mortality Risk Prediction by an Insurance Company and Long-Term Follow-Up of 62,000 Men. PLoS ONE 4(5), pp. 54-57.

61. State Statistics Service of Ukraine. - Official site. Available at: http://www.ukrstat.gov.ua/ (accessed 20 Desember 2019).

62. Sulaiman, L.A. et al. (2015). Investigating the factors influencing the life insurance market in Ethiopia. Problems and Perspectives in Management, 13(2-1), pp. 152-160.

63. Summary of Provisions on Genetic Discrimination in other Jurisdictions. Canadian Coalition for Genetic Fairness (CCGF). Available at http://ccgf-cceg.ca/en/home/, (accessed 20 April 2019).

64. Thomas, R. Guy (2018). Why Insurers Are Wrong about Adverse Selection. Laws 2018, 7, 13. MDPI.

65. Tiller, J., Keogh, L., Wake, S., Delatycki, M., Otlowski, M. \& Lacaze, P. (2018). Genetics, Insurance and Professional Practice: Survey of the Australasian Clinical Genetics Workforce. Front. Public Health, 6:333. doi:10.3389/fpubh.2018.00333

66. Tsendsuren, S., Li, C.-S., Peng, S.-C., Wong, W.-K. (2018). The Effects of Health Status on Life Insurance Holdings in 16 European Countries. Sustainability, 10, 3454.

67. Universal Declaration on the Human Genome and Human Rights. Available at: http://portal.unesco.org (accessed 10 May 2019).

68. Wong, Hector (2017). Seeing the Future? How Genetic Testing Will Impact Life Insurance. Swiss Re, Asia. 
69. Yildirim, İ. \& Çakar, R. (2015). A study on the factors affecting the insurance company preferences of insurance agencies in Turkey. International journal of business and management studies, Vol. 7, No 1.

70. Zolotarova, O. \& Galaganov, V. (2017). Actual Problems and Prospects for Development of Life Insurance in Ukraine. Ekonomika i Suspil'stvo (Economy and Society), № 10, pp.589597. (Original work written in Ukrainian).

71. Zoltick, E.S., Linderman, M.D., McGinniss, M.A. et al. (2019). Predispositional genome sequencing in healthy adults: design, participant characteristics, and early outcomes of the PeopleSeq Consortium. Genome Medicine, 11:10. https://doi.org/10.1186/s13073-019-0619-9 